\title{
Effects of pH on ferri-cyanide uptake and assimilation by several plants
}

\author{
X. Z. Yu $\cdot$ F. Li $\cdot$ K. Li
}

Received: 23 November 2010/Revised: 13 January 2011/Accepted: 10 December 2011/Published online: 17 March 2012

(c) CEERS, IAU 2012

\begin{abstract}
This paper presents an investigation of the capacity of four different plants to remove and assimilate ferri-cyanide at different $\mathrm{pH}$ conditions. Detached roots of weeping willows (Salix babylonica L.), rice (Oryza sativa L. cv. JY 98), soybean (Glycine max L. cv. WH) and maize (Zea mays L. var. HK) were hydroponically exposed to ferri-cyanide in a closed system at $25 \pm 0.5^{\circ} \mathrm{C}$ for $24 \mathrm{~h}$ kept under darkness. Almost all applied ferri-cyanide was in the complex form in the hydroponic solution at $\mathrm{pH} \geq 7.0$ in the absence of light, while dissociation of ferri-cyanide to free cyanide and iron in solution was detected at $\mathrm{pH} \leq 6.5$. All plant species used were found to be able to remove and assimilate ferri-cyanide efficiently. The uptake and assimilation rates appeared to be inversely related to the $\mathrm{pH}$, in which positive effects were observed at $\mathrm{pH} 6.0$ and 6.5. Remarkable decreases in the assimilation rates were found at $\mathrm{pH}$ 8.0. Results presented here suggest that changes in solution $\mathrm{pH}$ have a substantial influence on not only the speciation of ferricyanide in the plant growth media, but also the uptake and assimilation mechanisms of ferri-cyanide by plants.
\end{abstract}

Keywords Assimilation - Ferri-cyanide - Solution pH · Speciation · Plants

\section{Introduction}

Free cyanide ( $\mathrm{CN}$ and $\mathrm{HCN})$ is a high-volume production chemical and commonly used in a range of industrial

\section{Z. Yu $(\bowtie) \cdot$ F. Li · K. Li}

Department of Environmental Sciences and Engineering,

Hunan Agricultural University, Changsha 41028,

People's Republic of China

e-mail: yuxiaozhang@hotmail.com products (Yu et al. 2004), which result in a significant release of cyanide into the environment on a continuous basis. Indeed, it is estimated that more than 100,000 tons of anthropogenic cyanide enters the environment annually (Mudder and Botz 2001). Due to its chemical properties, free $\mathrm{CN}$ readily reacts with metal ions to form metal-cyanide complexes. Of the metal-cyanide complexes frequently detected, iron CNs, e.g., ferro-cyanide $\left[\mathrm{Fe}^{\mathrm{II}}(\mathrm{CN})_{6}\right]^{-4}$ and ferri-cyanide $\left[\mathrm{Fe}^{\mathrm{III}}(\mathrm{CN})_{6}\right]^{-3}$ are the most stable and common species found in soils and groundwater (Meeussen et al. 1992), which account for more than $97 \%$ of the total cyanide (Theis et al. 1994; Mansfeldt et al. 2004). Both compounds, though less toxic than free $\mathrm{CN}$, are environmentally problematic because free $\mathrm{CN}$ can be liberated from them through photodecomposition (Meeussen et al. 1992; Rader et al. 1993; Zimmerman et al. 2008). It is evident that the dissociation rate of ferri-cyanide is significantly higher than that of ferro-cyanide (Yu et al. 2011). Because the extensive use of $\mathrm{CN}$-containing chemicals due to anthropogenic activities has drastically changed the distribution and biochemical balance in the environment, the importance of potentially adverse and toxic effects on the ecosystems is of crucial significance due to the build up of free $\mathrm{CN}$ liberated from iron CNs. Therefore, efforts of complete destruction of iron CNs are of critical concern. Unfortunately, most of engineering approaches cause heavy disturbance to the ecosystems (Smith and Mudder 1991; Meeussen et al. 1992). It is known that iron cyanide complexes are quite resistent to attack by microbe and fungi (Ghosh et al. 1999; Meeussen et al. 1992), but there is abundant literature showing that plants are capable of tolerating, transporting and assimilating iron CNs (Samiotakis and Ebbs 2004; Larsen and Trapp 2006; Ebbs et al. 2008; Yu and Gu 2010). A variety of environmental factors affect the mechanism and efficiency of phytoremediation. This is largely because plant growth and 
development mainly depends on genotype as well as the environment. For instance, the change of $\mathrm{pH}$ may alter the stability and fate of chemicals, subsequently transform parent compound into other compounds, which may have different toxicities and bioavailability than the original compounds (Salt et al. 1998). It is evident that the speciation of ferri-cyanide is associated with numerous biotic and abiotic factors. Indeed, the change of solution $\mathrm{pH}$ most likely causes the dissociation of iron CNs and the rate appeared to be inversely related to the $\mathrm{pH}$ (Meeussen et al. 1995; Rennert and Mansfeldt 2002; Ghosh et al. 2004).

If the dissociation of ferri-cyanide into free $\mathrm{CN}$ and $\mathrm{Fe}^{3+}$ occurs before uptake by plants, $\left[\mathrm{Fe}^{\mathrm{III}}(\mathrm{CN})_{6}\right]^{-3}, \mathrm{HCN}$ and $\mathrm{CN}^{-}$may exist together in ferri-cyanide solution. Eventually, the uptake pathway of ferri-cyanide due to the presence of free $\mathrm{CN}$ will be different. It is known that ferricyanide is less phytoavailable to plants than free $\mathrm{CN}$ (Samiotakis and Ebbs 2004; Larsen and Trapp 2006; Ebbs et al. 2008; Yu and Gu 2010). This is largely due to the fact that ferri-cyanide is unable to move through biological membranes by simple diffusion due to its physical-chemical properties (Federico and Giartosio 1983; Ebbs et al. 2003). The goals of this study were to investigate the speciation of ferri-cyanide at different $\mathrm{pH}$ using a closeddark hydroponic system, and to compare the uptake and assimilation of ferri-cyanide by the dicot (soybean and willow) and the monocot (maize and rice). This work was conducted at the Department of Environmental Sciences and Engineering, Hunan Agricultural University, PR China, from January 2010 to March 2010.

\section{Materials and methods}

\section{Plant materials}

Seeds of soybean (Glycine max L. cv. WH), rice (Oryza sativa L. cv. JY 98), and maize (Zea mays L. var. HK) after cleaning were planted under laboratory condition at $25^{\circ} \mathrm{C}$ until shoots appeared. Hoagland's nutrient solution at $25 \%$ strength was used to support plant growth. Seedlings were harvested after 12-15 days of growth. Cuttings of weeping willows (Salix babylonica L.) were removed from a single mature tree and placed in buckets of tap water at $25^{\circ} \mathrm{C}$ under until new roots appeared.

Plants with new shoots and roots were transferred to a pretreatment solution containing $1 \mathrm{mM} \mathrm{CaCl}_{2}+2 \mathrm{mM}$ MES-TRIS buffer (pH 6.0) for $24 \mathrm{~h}$ to clear the cell wall space of ions (Ebbs et al. 2008). Plant roots approximately $8-10 \mathrm{~cm}$ in length were excised from the root tip, and cut into small pieces to use in the subsequent experiments.

Potassium ferri-cyanide $\left[\mathrm{K}_{3} \mathrm{Fe}(\mathrm{CN})_{6}\right]$ (Sinopharm Chemical Reagent Co., Ltd., Shanghai, PR China) of analytical grade with $\geq 95 \%$ purity was used. It should be noted that $1 \mathrm{mg} \mathrm{K}_{3} \mathrm{Fe}(\mathrm{CN})_{6}$ equal to $0.474 \mathrm{mg} \mathrm{CN}$.

Effect of $\mathrm{pH}$ on ferri-cyanide uptake by detached roots

Excised roots were precisely weighted (1.0 g fresh weight) and placed in $50-\mathrm{mL}$ flasks. Then $50-\mathrm{mL}$ spiked aqueous solution (deionized oxygen-saturated water) containing potassium ferri-cyanide was added. The initial $\mathrm{pH}$ of spiked solutions was variable. Five different $\mathrm{pH}$ solutions of 6.0 (Treatment 1), 6.5 (Treatment 2), 7.0 (Control), 7.5 (Treatment 3) and 8.0 (Treatment 4) were used by adding $0.1 \% \mathrm{HCl}$ and $0.1 \% \mathrm{NaOH}$. The flasks were closed with glass stopper. All flasks wrapped with aluminum foil were housed at an incubator with a constant temperature $25 \pm 0.5^{\circ} \mathrm{C}$ for $24 \mathrm{~h}$. Three replicates were prepared for each treatment. One set of control in three replicates (the flasks were also wrapped with aluminum foils) was only with the testing chemical, but without plant materials to quantify the loss and dissociation of ferri-cyanide within the testing system at different $\mathrm{pH}$ during the exposure period.

\section{Chemical analysis}

\section{Analysis of free $C N$ and total $C N$}

The presence of total $\mathrm{CN}$ and free $\mathrm{CN}$ in solution were all analyzed just prior to application and at the termination of exposure. Total $\mathrm{CN}$ in excised roots were also analyzed after $24 \mathrm{~h}$ of exposure.

The concentrations of free $\mathrm{CN}$ and total cyanide in the aqueous solution were determined spectrophotometrically by a standard method (State Environmental Protection Administration of China, 1989, method number GB 7487-87) as described previously ( $\mathrm{Yu}$ and $\mathrm{Gu} 2010$ ).

The analysis of total $\mathrm{CN}$ in plant tissues was also analyzed by a standard distillation method (State Environmental Protection Administration of China, 1989, method number GB 7486-87). After exposure of $24 \mathrm{~h}$, the excised roots were collected and rinsed with water. The remaining procedures were identical to those described previously (Yu and Gu 2010).

Analysis of $\mathrm{Fe}^{3+} / \mathrm{Fe}^{2+}$ in solution

Dissolved $\mathrm{Fe}^{2+}$ concentration was determined by the ferrozine method as described previously (Gibbs 1979). The total dissolved $\mathrm{Fe}$ including dissolved $\mathrm{Fe}^{2+}$ and $\mathrm{Fe}^{3+}$ was measured by reducing total dissolved $\mathrm{Fe}$ into $\mathrm{Fe}^{2+}$, and then $\mathrm{Fe}^{2+}$ was determined by the ferrozine method without addition of sodium fluoride $(\mathrm{NaF})$ solution (Greenberg et al. 1992). The content of dissolved $\mathrm{Fe}^{3+}$ in solution was 
obtained by computing the difference between total dissolved $\mathrm{Fe}$ and dissolved $\mathrm{Fe}^{2+}$.

Determination of the assimilation rate of ferri-cyanide

The assimilation rate of ferri-cyanide $v(\mu \mathrm{g} \mathrm{CN} / \mathrm{g} \mathrm{FW} \mathrm{h})$ was calculated from

$v=\frac{m_{(\mathrm{I})}-m_{(\mathrm{F})}-m_{(\mathrm{R})}}{\Delta t \times M}$

where $m_{(\mathrm{I})}, m_{(\mathrm{F})}$ and $m_{(\mathrm{R})}$ are the total $\mathrm{CN}(\mu \mathrm{g})$ in hydroponic solution and in roots. $M$ is the biomass of the roots $(\mathrm{g})$, and $\Delta t$ is the time period $(\mathrm{h})$.

Statistical methods

Analysis of variance (ANOVA) and Tukey's multiple range test was used to determine the statistical significance at 0.01 or 0.05 between the treatments (Sachs 1992).

\section{Results and discussion}

Speciation of ferri-cyanide in hydroponic solution

Speciation of ferri-cyanide in hydroponic solution at different $\mathrm{pH}$ in the absence of plant materials was tested (Table 1). In the solution at $\mathrm{pH} 7.0$, no obvious change of total $\mathrm{CN}$ in the hydroponic solution was observed over a 24-h period of exposure in the absence of light, while trace amounts of free $\mathrm{CN}$ were detected in the solution. In addition, the content of dissolved $\mathrm{Fe}^{3+}$ in the solution was negligible after analysis of the total dissolved $\mathrm{Fe}$ and $\mathrm{Fe}^{2+}$ in aqueous solution. Similar results were also observed in the solutions with higher $\mathrm{pH}$. These results indicated that dissociation of ferri-cyanide into free $\mathrm{CN}$ and $\mathrm{Fe}^{3+}$ in the hydroponic solution in the absence of light is negligible and almost all solution CNs at $\geq 7.0$ remained as ferricyanide. This is comparable to previous studies (Samiotakis and Ebbs 2004; Larsen and Trapp 2006; Ebbs et al.
2008; $\mathrm{Yu}$ and $\mathrm{Gu}$ 2010). Although negligible change of total $\mathrm{CN}$ in the hydroponic solution was found in the solution at $\mathrm{pH} 6.5$ after incubation, the concentrations of free $\mathrm{CN}$ and dissolved $\mathrm{Fe}^{3+}$ in the solution were determined to be $0.39 \mathrm{mg} \mathrm{CN} / \mathrm{L}$ and $0.14 \mathrm{mg} \mathrm{Fe} / \mathrm{L}$, respectively. It is known that the stoichiometric relationship between free $\mathrm{CN}$ and dissolved $\mathrm{Fe}^{3+}$ is 6.0. Indeed, the ratio of free $\mathrm{CN}$ to dissolved $\mathrm{Fe}^{3+}$ in the hydroponic solution at $\mathrm{pH} 6.5$ at the termination of exposure was approximately 6.0. More free $\mathrm{CN}$ and dissolved $\mathrm{Fe}^{3+}$ were detected in the solution with a decrease of solution $\mathrm{pH}$. This observation indicated that solution $\mathrm{pH}$ has a remarkable influence on dissociation of ferri-cyanide. It is of interest to note that less than $2 \%$ of the applied ferri-cyanide, judged by the total $\mathrm{CN}$ analyzed, was not found in the hydroponic solution, probably due to the fact that free $\mathrm{CN}$ liberated from ferri-cyanide escaped from the aqueous solution to the headspace. Therefore, these observations indicated that the disappearance of the applied ferri-cyanide in the solution could then be attributed to the uptake of plant materials.

Effects of $\mathrm{pH}$ on ferri-cyanide uptake and assimilation by detached roots

The effect of $\mathrm{pH}$ on the uptake and assimilation of ferricyanide by detached roots was investigated. For the treatment with soybean (Table 2), significant amounts of the applied ferri-cyanide were removed by plant roots from the hydroponic solution at $\mathrm{pH} 6.0$ compared to the control at pH $7.0(P<0.05)$, judged by the total $\mathrm{CN}$ analyzed. Although less applied ferri-cyanide was removed by soybean roots from the solution at $\mathrm{pH} 7.5$ and 8.0 compared to the control, the difference was not significant $(P>0.05)$. However, significant difference in the total $\mathrm{CN}$ detected in plant materials between the treatments was observed. Indeed, the $\mathrm{CN}$ concentrations in soybean roots exposed to ferri-cyanide at $\mathrm{pH} 6.0$ and 6.5 were significantly higher than that of the control at $7.0(P<0.05)$, while measureable difference was observed in the treatments at $\mathrm{pH} 7.5$ and 8.0 compared to the control $(P>0.05)$. Loss of the

Table 1 Speciation of ferri-cyanide in the hydroponic solution

\begin{tabular}{|c|c|c|c|c|c|c|c|}
\hline \multirow[t]{2}{*}{ Treatment } & \multicolumn{4}{|c|}{ Initial } & \multicolumn{3}{|l|}{ Final } \\
\hline & $\mathrm{pH}$ & $\begin{array}{l}\text { Conc. (T-CN) } \\
(\mathrm{mg} \mathrm{CN} / \mathrm{L})\end{array}$ & $\begin{array}{l}\text { Conc. (F-CN) } \\
(\mathrm{mg} \mathrm{CN} / \mathrm{L})\end{array}$ & $\begin{array}{l}\text { Conc. }\left(\mathrm{Fe}^{3+}\right) \\
(\mathrm{mg} \mathrm{Fe} / \mathrm{L})\end{array}$ & $\begin{array}{l}\text { Conc. (T-CN) } \\
\text { (mg CN/L) }\end{array}$ & $\begin{array}{l}\text { Conc. (F-CN) } \\
(\mathrm{mg} \mathrm{CN} / \mathrm{L})\end{array}$ & $\begin{array}{l}\text { Conc. }\left(\mathrm{Fe}^{3+}\right) \\
(\mathrm{mg} \mathrm{Fe} / \mathrm{L})\end{array}$ \\
\hline Solution-1 & 7.0 & 10.34 & 0.01 & 0.01 & $10.29(0.24)$ & $0.03(0.01)$ & $0.03(0.001)$ \\
\hline Solution-2 & 6.0 & 10.21 & 0.02 & 0.01 & $10.09(0.34)$ & $0.82(0.12)$ & $0.28(0.05)$ \\
\hline Solution-3 & 6.5 & 10.19 & 0.02 & 0.01 & $10.03(0.26)$ & $0.39(0.08)$ & $0.14(0.06)$ \\
\hline Solution-4 & 7.5 & 10.32 & 0.01 & 0.01 & $10.30(0.32)$ & $0.03(0.01)$ & $0.02(0.001)$ \\
\hline Solution-5 & 8.0 & 10.26 & 0.01 & 0.01 & $10.25(0.19)$ & $0.03(0.01)$ & $0.02(0.001)$ \\
\hline
\end{tabular}

Exposure period: $24 \mathrm{~h}$, the values are the mean of three replicates; in brackets: standard deviation 
Table 2 Measured total CN concentrations in hydroponic solution (mg CN/L) and in roots of soybean ( $\mu \mathrm{g}$ CN/g FW) exposed to ferri-cyanide solution at different $\mathrm{pH}$

\begin{tabular}{lllllll}
\hline Soybean & $\begin{array}{l}\text { Conc. }(\mathrm{I}) \\
(\mathrm{mg} \mathrm{CN} / \mathrm{L})\end{array}$ & $\begin{array}{l}\text { Conc. }(\mathrm{F}) \\
(\mathrm{mg} \mathrm{CN} / \mathrm{L})\end{array}$ & $\begin{array}{l}\text { Mass reduction } \\
(\%)\end{array}$ & $\begin{array}{l}\text { Conc. (root) } \\
(\mu \mathrm{g} / \mathrm{g} \mathrm{FW})\end{array}$ & $\begin{array}{l}\text { Mass recovery } \\
(\%)\end{array}$ & $\begin{array}{l}\text { Loss rate } \\
(\mu \mathrm{g} \mathrm{CN} / \mathrm{g} . \mathrm{h})\end{array}$ \\
\hline Control & $10.85(0.11)$ & $8.16(0.35)$ & $24.81(4.18)$ & $46.20(6.74)$ & $34.31(1.99)$ & $3.68(0.47)$ \\
Treatment-1 & $11.01(0.11)$ & $7.34(0.29)$ & $33.33(2.53)^{*}$ & $83.70(7.14)^{*}$ & $45.67(3.34)$ & $4.16(0.47)$ \\
Treatment-2 & $11.17(0.11)$ & $7.82(0.24)$ & $30.04(2.17)$ & $71.29(6.48)^{*}$ & $42.47(1.54)$ & $4.02(0.28)$ \\
Treatment-3 & $11.09(0.22)$ & $8.77(0.12)$ & $20.95(1.09)$ & $41.72(2.99)$ & $35.87(0.82)$ & $3.10(0.13)$ \\
Treatment-4 & $10.30(0.22)$ & $8.11(0.32)$ & $21.31(3.11)$ & $44.62(3.74)$ & $40.93(3.02)$ & $2.71(0.53)^{*}$ \\
\hline
\end{tabular}

Exposure period: $24 \mathrm{~h}$, the values are the mean of three replicates; in brackets: standard deviation

$F W$ fresh weight

* Refers to the significant difference between the treatment and the control $(P<0.05)$

Table 3 Measured total CN concentrations in hydroponic solution (mg CN/L) and in roots of weeping willows ( $\mu \mathrm{g}$ CN/g FW) exposed to ferricyanide solution at different $\mathrm{pH}$

\begin{tabular}{lllllrr}
\hline Willows & $\begin{array}{l}\text { Conc. }(\mathrm{I}) \\
(\mathrm{mg} \text { CN/L) }\end{array}$ & $\begin{array}{l}\text { Conc. }(\mathrm{F}) \\
(\mathrm{mg} \mathrm{CN} / \mathrm{L})\end{array}$ & $\begin{array}{l}\text { Mass reduction } \\
(\%)\end{array}$ & $\begin{array}{l}\text { Conc. }(\text { root }) \\
(\mu \mathrm{g} / \mathrm{g} \mathrm{FW})\end{array}$ & $\begin{array}{l}\text { Mass recovery } \\
(\%)\end{array}$ & $\begin{array}{l}\text { Loss rate } \\
(\mu \mathrm{g} \mathrm{CN} / \mathrm{g} \mathrm{h})\end{array}$ \\
\hline Control & $10.86(0.11)$ & $6.18(0.10)$ & $43.06(0.97)$ & $28.78(1.99)$ & $12.34(1.13)$ & $8.53(0.30)$ \\
Treatment-1 & $10.69(0.11)$ & $4.62(0.20)$ & $56.78(1.86)^{*}$ & $26.67(1.65)$ & $8.80(0.81)^{*}$ & $11.53(0.47)^{*}$ \\
Treatment-2 & $10.93(0.45)$ & $5.17(0.09)$ & $52.65(0.84)^{*}$ & $27.99(2.99)$ & $9.72(0.96)$ & $10.82(0.15)^{*}$ \\
Treatment-3 & $10.53(0.56)$ & $6.02(0.05)$ & $42.83(0.75)$ & $19.54(2.55)^{*}$ & $8.67(1.67)^{*}$ & $8.58(0.21)$ \\
Treatment-4 & $10.53(0.34)$ & $6.57(0.21)$ & $37.57(1.99)$ & $16.63(1.58)^{*}$ & $8.43(1.01)^{*}$ & $7.55(0.45)$ \\
\hline
\end{tabular}

Exposure period: $24 \mathrm{~h}$, the values are the mean of three replicates; in brackets: standard deviation

$F W$ fresh weight

* Refers to the significant difference between the treatment and the control $(P<0.05)$

applied ferri-cyanide from the control without plant materials was negligible, as a result, all loss was likely to be botanical assimilation. The calculated loss rates are shown in Table 2. The change of solution $\mathrm{pH}$ did not show significant effect on the assimilation rate of ferri-cyanide by soybean roots $(\mathrm{pH}>0.05)$, except the treatment at $\mathrm{pH}$ 8.0. The loss rate of ferri-cyanide was $3.68 \mathrm{mg} \mathrm{CN} / \mathrm{g} \cdot \mathrm{h}$ at the control, while the assimilation rate was $2.71 \mathrm{mg} \mathrm{CN} / \mathrm{g} \cdot \mathrm{h}$ at $\mathrm{pH} 8.0$.

When the roots of willows were exposed to ferri-cyanide solution at $\mathrm{pH} 6.0$ and 6.5 , significant amounts of the applied mass were removed by plant materials compared to the control at pH $7.0(P<0.05)$, judged by the total $\mathrm{CN}$ analyzed. However, no significant difference in ferricyanide removal $(\%)$ was observed in the treatments at $\mathrm{pH}$ 7.5 and 8.0 compared to the control $(P>0.05)$. The recovered CNs in plant materials detected as total $\mathrm{CN}$ after exposure were also difference between the treatments. The $\mathrm{CN}$ concentration in willow roots exposed to ferri-cyanide at pH 6.0 and 6.5 slightly lower than that of the control at $\mathrm{pH} 7.0(P>0.05)$, while significantly lower $\mathrm{CN}$ concentrations were detected in the plant materials exposed to ferri-cyanide solution at 7.5 and 8.0 compared to the control $(P<0.05)$. Therefore, the calculated assimilation rates of ferri-cyanide are shown in Table 3. It is obvious that the change of solution $\mathrm{pH}$ caused difference responses to willow roots during the botanical assimilation of ferricyanide. Although measurable effects on the assimilation rates of ferri-cyanide by willow roots were observed at $\mathrm{pH}$ 7.5 and $8.0(P>0.05)$, significantly higher assimilation rates were found in the treatments at $\mathrm{pH} 6.0$ and 6.5 $(P<0.05)$.

For the control with maize roots exposed to ferri-cyanide solution at $\mathrm{pH} 7.0$, more than $48 \%$ of the applied ferricyanide was removed from the hydroponic solution. The uptake rates of ferri-cyanide by plant materials varied with solution pH. Significant amounts of the applied ferricyanide were removed by maize roots from the hydroponic solution at $\mathrm{pH} 6.0$ and 6.5 compared to the control $(P<0.05)$. However, less applied ferri-cyanide was removed by roots exposed to the solution at $\mathrm{pH} 7.5$ and 8.0 compared to the control, and the difference was not significant $(P>0.05)$. The $\mathrm{CN}$ concentrations in plant materials between the treatments were also variable, judged by the total $\mathrm{CN}$ analyzed. When exposed to the solution at $\mathrm{pH}$ 6.0 and 6.5, significant amounts of ferri-cyanide were accumulated in maize roots compared to the control $(P<0.05)$. However, the recovery rates of ferri-cyanide, 
Table 4 Measured total CN concentrations in hydroponic solution (mg CN/L) and in roots of maize ( $\mu \mathrm{g}$ CN/g FW) exposed to ferri-cyanide solution at different $\mathrm{pH}$

\begin{tabular}{lllllll}
\hline Maize & $\begin{array}{l}\text { Conc. }(\mathrm{I}) \\
(\mathrm{mg} \mathrm{CN} / \mathrm{L})\end{array}$ & $\begin{array}{l}\text { Conc. }(\mathrm{F}) \\
(\mathrm{mg} \mathrm{CN} / \mathrm{L})\end{array}$ & $\begin{array}{l}\text { Mass reduction } \\
(\%)\end{array}$ & $\begin{array}{l}\text { Conc. (root) } \\
(\mu \mathrm{g} / \mathrm{g} \mathrm{FW})\end{array}$ & $\begin{array}{l}\text { Mass recovery } \\
(\%)\end{array}$ & $\begin{array}{l}\text { Loss rate } \\
(\mu \mathrm{g} \mathrm{CN} / \mathrm{g} . \mathrm{h})\end{array}$ \\
\hline Control & $10.93(0.22)$ & $5.60(0.71)$ & $48.79(6.54)$ & $154.98(27.4)$ & $57.93(4.29)$ & $4.65(0.58)$ \\
Treatment-1 & $9.27(0.11)$ & $1.85(0.48)$ & $80.06(5.22)^{*}$ & $255.48(32.1)^{*}$ & $60.55(4.82)$ & $6.07(0.33)^{*}$ \\
Treatment-2 & $9.11(0.11)$ & $2.38(0.16)$ & $72.92(1.74)^{*}$ & $199.60(15.3)^{*}$ & $59.23(3.16)$ & $5.71(0.32)^{*}$ \\
Treatment-3 & $10.69(0.34)$ & $6.12(0.24)$ & $42.70(2.26)$ & $130.69(11.2)$ & $57.20(1.89)$ & $4.06(0.07)$ \\
Treatment-4 & $10.61(0.67)$ & $6.49(0.42)$ & $38.78(3.95)$ & $134.39(21.3)$ & $65.14(4.88)$ & $2.97(0.35)^{*}$ \\
\hline
\end{tabular}

Exposure period: $24 \mathrm{~h}$, the values are the mean of three replicates; in brackets: standard deviation

$F W$ fresh weight

* Refers to the significant difference between the treatment and the control $(P<0.05)$

Table 5 Measured total $\mathrm{CN}$ concentrations in hydroponic solution (mg CN/L) and in roots of rice ( $\mu \mathrm{g}$ CN/g FW) exposed to ferri-cyanide solution at different $\mathrm{pH}$

\begin{tabular}{lllllll}
\hline Rice & $\begin{array}{l}\text { Conc. }(\mathrm{I}) \\
(\mathrm{mg} \mathrm{CN} / \mathrm{L})\end{array}$ & $\begin{array}{l}\text { Conc. }(\mathrm{F}) \\
(\mathrm{mg} \mathrm{CN} / \mathrm{L})\end{array}$ & $\begin{array}{l}\text { Mass reduction } \\
(\%)\end{array}$ & $\begin{array}{l}\text { Conc. }(\mathrm{root}) \\
(\mu \mathrm{g} / \mathrm{g} \mathrm{FW})\end{array}$ & $\begin{array}{l}\text { Mass recovery } \\
(\%)\end{array}$ & $\begin{array}{l}\text { Loss rate } \\
(\mu \mathrm{g} \mathrm{CN} / \mathrm{g} . \mathrm{h})\end{array}$ \\
\hline Control & $9.84(0.11)$ & $3.19(0.15)$ & $68.23(1.54)$ & $127.26(5.83)$ & $38.34(2.65)$ & $8.54(0.56)$ \\
Treatment-1 & $10.03(0.67)$ & $2.36(0.13)$ & $82.16(1.32)$ & $166.07(2.78)$ & $41.86(1.35)$ & $9.62(0.38)$ \\
Treatment-2 & $10.22(0.22)$ & $2.84(0.03)$ & $75.79(5.22)$ & $158.15(12.9)$ & $42.84(3.39)$ & $8.79(0.50)$ \\
Treatment-3 & $10.06(0.34)$ & $2.93(0.24)$ & $70.87(2.36)$ & $200.13(17.8)^{*}$ & $56.07(3.14)^{*}$ & $6.51(0.25)^{*}$ \\
Treatment-4 & $9.74(0.11)$ & $3.89(0.31)$ & $60.02(3.16)$ & $163.17(8.39)$ & $55.87(1.40)^{*}$ & $5.38(0.44)^{*}$ \\
\hline
\end{tabular}

Exposure period: $24 \mathrm{~h}$, the values are the mean of three replicates; in brackets: standard deviation

$F W$ fresh weight

* Refers to the significant difference between the treatment and the control $(P<0.05)$

judged by the total $\mathrm{CN}$ analyzed, in plant materials exposed to the solution at $\mathrm{pH} 7.5$ and 8.0 were slightly different to the control $(P>0.05)$. The change of solution $\mathrm{pH}$ had significant effects on the loss rate of ferri-cyanide by maize roots, except the treatment at $\mathrm{pH} 7.5$. The loss rates of ferricyanide at 6.0 and 6.5 were significantly higher than that of control $(P<0.05)$, while a remarkable decrease of the loss rate was observed at $\mathrm{pH} 8.0(P<0.05)$ (Table 4$)$.

The uptake rate of ferri-cyanide by rice roots did not vary with solution $\mathrm{pH}(P>0.05)$, in which between 60.02 and $82.16 \%$ of the applied ferri-cyanide was removed from the hydroponic solutions at different $\mathrm{pH}$. However, the $\mathrm{CN}$ concentrations in plant materials between the treatments were variable, judged by the total $\mathrm{CN}$ analyzed. 56.07 and $55.87 \%$ of the ferri-cyanide loss from the hydroponic solution were recovered in plant materials at $\mathrm{pH} 7.5$ and 8.0 , while approximate $38 \%$ were detected in rice roots exposed to the solution at $\mathrm{pH}$ 7.0. The calculated loss rats of ferri-cyanide are shown in Table 5. Although higher assimilation rates of ferri-cyanide were observed at $\mathrm{pH} 6.0$ and 6.5 compared to the control, the difference was not significant $(P>0.05)$. For the treatments at $\mathrm{pH} 7.5$ and 8.0, a remarkable decrease in the loss rate was detected compared to the control $(P<0.05)$.
Comparison to other findings

Although all plants selected were found to be able to assimilate ferri-cyanide efficiently in this study, the assimilation rates varied with plant species. Rice showed the fastest assimilation capacity for ferri-cyanide and the lowest had the soybean. There is abundant literature showing that dicot and monocot have different strategies to acquire Fe from the soils (Kim and Guerino 2007). Grass plants (monocot) use the chelation-based strategy to acquire $\mathrm{Fe}$ in the presence of $\mathrm{Fe}$-chelating substances phytosiderophores excreted by roots (Harada et al. 2007). It is known that the equilibrium constant $(\log K)$ is 52.63 for ferri-cyanide (Meeussen et al. 1992), while the $\log K$ value of Fe-phytosiderophores is only 18.1 (Mino et al. 1983). Therefore, the liberation of ferri-cyanide is highly unlikely to occur in the solution, due to the presence of phytosiderophores excreted by roots of grass plants. A reductionbased strategy is a Fe-acquisition mechanism commonly found in higher plants (dicot), in which Fe becomes more phytoavailable by reducing $\mathrm{Fe}^{3+}$ to the more soluble $\mathrm{Fe}^{2+}$ in the presence of $\mathrm{Fe}^{3+}$ reductase at the root cell's plasma membrane (Kim and Guerino 2007). Indeed, it has been found in our previous work that ferro-cyanide is more 
bioavailable to plants than ferri-cyanide (Yu and $\mathrm{Gu} 2010)$. However, it is not a general rule in this observation showing that the dicot assimilated ferri-cyanide faster than the monocot, in which soybean, stemming from a dicot family, had a lower assimilation capacity than rice belonging to the monocot. Therefore, the effect of the reductase enzyme involved in reduction of $\mathrm{Fe}^{3+}$ to $\mathrm{Fe}^{2+}$ at the root surface was negligible.

Previous studies (Meeussen et al. 1992; Ebbs et al. 2008; $\mathrm{Yu}$ and $\mathrm{Gu} 2010$ ) collectively suggested that the dissociation of iron CNs in the absence of light was detected, but the rates appeared to be extremely slow. Indeed, trace amounts of free $\mathrm{CN}$ and dissolved $\mathrm{Fe}^{3+}$ was detected in the solution in this study, suggesting that $\mathrm{CNs}$ in the solution at $\mathrm{pH} \geq 7.0$ remained principally in the form of ferri-cyanide before uptake by plant roots. In our observation, plants showed different responses to the change of solution $\mathrm{pH}$ during the assimilation of ferri-cyanide. No significant impact on the assimilation rate was observed in plants exposed to ferri-solution at $\mathrm{pH} 7.5$ in all treatments compared to the control at $\mathrm{pH} 7.0$, except the treatment with rice. However, all plants, except willows, showed a negative response to the change of $\mathrm{pH}$ at 8.0, implying that the botanical assimilation of ferri-cyanide was largely inhibited at $\mathrm{pH} 8.0$, even though the removal rate $(\%)$ of free cyanide from the hydroponic solution did not show any inhibitory effect.

It is known that plants are able to assimilate free $\mathrm{CN}$ readily, without accumulation in plant materials (Miller and Conn 1980; Larsen et al. 2005). In this study, significant amounts of $\mathrm{CN}$ detected as total $\mathrm{CN}$ were observed in plant tissues at the termination of exposure, implying that ferri-cyanide was probably still in the same original complexed form in plant materials (Larsen and Trapp 2006). Therefore, this suggests that direct assimilation of ferri-cyanide in plant materials is possible, without phytodissociation into free $\mathrm{CN}$.

What causes the increase in the assimilation rate of ferri-cyanide?

It has been reported that the dissociation rate of iron CNs appeared to be inversely related to the $\mathrm{pH}$ (Meeussen et al. 1992). In this study, free $\mathrm{CN}$ in the solution spiked with ferri-cyanide was detected to be $0.39 \mathrm{mg} \mathrm{CN} / \mathrm{L}$ at $\mathrm{pH} 6.5$ after a 24-h period of exposure, while more free $\mathrm{CN}$ was found in the treatment at $\mathrm{pH}$ 6.0. It is of interest to note that approximately $2 \%$ of the applied ferri-cyanide was unable to be detected in the solution, probably due to the fact that free $\mathrm{CN}(\mathrm{HCN})$ liberated from ferri-cyanide escaped from the aqueous solution to the headspace. Therefore, there is a good reason to suggest that $\left[\mathrm{Fe}^{\mathrm{III}}(\mathrm{CN})_{6}\right]^{-3}, \mathrm{HCN}$ and $\mathrm{CN}^{-}$ occur together in ferri-cyanide solution in proportions, which will not only affect the uptake rate of ferri-cyanide, but also eventually change the assimilation pathway in plant materials. Indeed, higher uptake and assimilation rates of ferri-cyanide, judged by the total $\mathrm{CN}$ analyzed, were found in the all treatments at $\mathrm{pH} 6.0$ and 6.5 compared to the control at $\mathrm{pH}$ 7.0.

While it is known that botanical uptake of free $\mathrm{CN}$ is principally achieved by simple diffusion (Dzombak et al. 2005), there is no evidence available on the uptake of ferricyanide mediated by membrane transporters because iron $\mathrm{CNs}$ has long been considered membrane impermeable (Federico and Giartosio 1983). However, our study presented here and also others' (Samiotakis and Ebbs 2004; Larsen and Trapp 2006; Ebbs et al. 2008; Yu and Gu 2010) collectively indicated plants are able to take up $\mathrm{Fe}^{3+}$ and free $\mathrm{CN}$ as a complex. Evidence of the beta-cyanoalanine synthase pathway responsible for the assimilation of free $\mathrm{CN}$ in plants is well defined (Miller and Conn 1980; Samiotakis and Ebbs 2004; Yu et al. 2004; Larsen et al. 2005), but there is no literature available showing the direct assimilation of ferri-cyanide in plant materials. Further study will be required to provide biochemical evidence to clarify the specific mechanisms involved in the uptake and assimilation of ferri-cyanide by plants.

\section{Conclusion}

All plants used in this study were able to efficiently remove ferri-cyanide from the hydroponic solution and assimilate this compound in plant materials, but the rates varied with plant species. Solution $\mathrm{pH}$ strongly affected the speciation of ferri-cyanide, subsequently changed the uptake and assimilation pathway. The assimilation rates appeared to be inversely related to the solution $\mathrm{pH}$. Our information collectively suggests that all plants showed a higher assimilation rate of ferri-cyanide at $\mathrm{pH} 6.0$ due to amounts of free $\mathrm{CN}$ liberated from this complex, but the rate was significantly inhibited at $\mathrm{pH}$ 8.0.

Acknowledgments This work was financially supported by The National Nature Science Foundation of China (NSFC: 40971256).

\section{References}

Dzombak DA, Ghosh RS, Young TC (2005) Physical-chemical properties and reactivity of cyanide in water and soil. In: Dzombak DA, Ghosh RS, Wong-Chong GW (eds) Cyanide in water and soil: chemistry, risk, and management. CRC, Boca Raton, USA, pp 58-92

Ebbs SD, Bushey J, Poston S, Kosma D, Samiotakis M, Dzombak D (2003) Transport and metabolism of free cyanide and iron cyanide complexes by willow. Plant Cell Environ 26(9):14671478 
Ebbs SD, Piccinin RC, Goodger JQD, Kolev SD, Woodrow IW, Baker AJM (2008) Transport of ferrocyanide by two eucalypt species and sorghum. Int J Phytoremediation 10(4):343-357

Federico R, Giartosio CE (1983) A transplasmamembrane electron transport system in maize. Plant Physiol 73(1):182-184

Ghosh RS, Dzombak DA, Luthy RG, Nakles DV (1999) Subsurface fate and transport of cyanide species at a manufactured-gas plant site. Water Environ Res 71(6):1205-1216

Ghosh RS, Nakles DV, Murarka P, Neuhauser EF (2004) Cyanide speciation in soil and groundwater at manufactured gas plant (MGP) sites. Environ Eng Sci 21(6):752-767

Gibbs MM (1979) A simple method for the rapid determination of iron in natural waters. Water Res 13(3):295-297

Greenberg AE, Clesceri LSE, Eaton AD (1992) Standard methods for the examination of water and wastewater. American Water Works Association, Water Pollution Control Federation, Washington, pp 366-368

Harada E, Sugase K, Namba K, Iwashita T, Murata Y (2007) Structural element responsible for the Fe(III)-phytosiderophores specific transport by HvYS1 transporter in barley. FEBS Lett 581(22):4298-4302

Kim SA, Guerino ML (2007) Mining iron: iron uptake and transport in plants. FEBS Lett 581(12):2273-2280

Larsen M, Trapp S (2006) Uptake of iron cyanide complexes into willow trees. Environ Sci Technol 40(6):1956-1961

Larsen M, Ucisik A, Trapp S (2005) Uptake, metabolism, accumulation and toxicity of cyanide in willow trees. Environ Sci Technol 39(7):2135-2142

Mansfeldt T, Leyer H, Barmettler K, Kretzschmar R (2004) Cyanide leaching from soil developed from coking plant purifier waste as influenced by citrate. Vadose Zone J. 3(3):471-479

Meeussen JCL, Keizer MG, de Haan FAM (1992) Chemical stability and decomposition rate of iron cyanide complexes in soil solutions. Environ Sci Technol 26(3):511-516

Meeussen JCL, van Riemsdijk WH, van der Zee SEATM (1995) Transport of complexed cyanide in soil. Geoderma 67(1):73-85

Miller JM, Conn EE (1980) Metabolism of hydrogen cyanide by higher plants. Plant Physiol 65(6):1199-1202
Mino Y, Ishida T, Ota N, Inoue M, Nomoto K, Takemoto T, Tanaka H, Sugiura Y (1983) Mugineic acid-iron (III) complex and its structurally analogous cobalt (III) complex: characterization and implication for absorption and transport of iron in gramineous plants. J Am Chem Soc 105(14):4611-4676

Mudder T, Botz M (2001) A guide to cyanide. Mining Environ Manag 9(3):8-12

Rader WS, Solujic L, Milosavljevic EB, Hendrix JL, Nelson JH (1993) Sunlight-induced photochemistry of aqueous solutions for hexacyanoferrate (II) and (III) ions. Environ Sci Technol 27(9): 1875-1879

Rennert T, Mansfeldt T (2002) Sorption of iron-cyanide complexes on goethite in the presence of sulfate and desorption with phosphate and chloride. J Environ Qual 31(3):745-751

Sachs L (1992) Angewandte Statistik. Springer, Berlin

Salt DE, Smith RD, Raskin I (1998) Phytoremediation. Ann Rev Plant Physiol Plant Mol Biol 49(3):643-668

Samiotakis M, Ebbs SD (2004) Possible evidence for transport of an iron cyanide complex by plants. Environ Pollut 127(2):169-173

Smith A, Mudder T (1991) The chemistry and treatment of cyanide waste. Mining Journal Book Ltd., London

Theis TL, Young TC, Huang M, Knutsen KC (1994) Leachate characteristics and composition of cyanide-bearing wastes from manufactured gas plants. Environ Sci Technol 28(1):99-106

Yu XZ, Gu JD (2010) Effect of temperature on removal of iron cyanides from solutions by maize plants. Environ Sci Pollut Res 17(1):106-114

Yu XZ, Trapp S, Zhou PH, Wang C, Zhou XS (2004) Metabolism of cyanide by Chinese vegetation. Chemosphere 56(2):121-126

Yu XZ, Peng XY, Wang GL (2011) Photo-induced dissociation of ferri- and ferro-cyanide in hydroponic solutions. Int J Environ Sci Technol 8(4):853-862

Zimmerman AR, Kang DH, Ahn MY, Hyun S, Banks MK (2008) Influence of a soil enzyme on iron-cyanide complex speciation and mineral adsorption. Chemosphere 70(6):1044-1051 